\title{
Impact of Rehabilitation with Metal-Ceramic Restorations on Oral Health-Related Quality of Life
}

\author{
Gisele Rodrigues da SILVA ${ }^{1}$ \\ Marina Guimarães ROSCOE ${ }^{1}$ \\ Cristianne Pacheco RIBEIRO ${ }^{1}$ \\ Adérito Soares da MOTA ${ }^{1}$ \\ Luís Roberto Marcondes MARTINS ${ }^{2}$ \\ Carlos José SOARES ${ }^{1}$
}

\begin{abstract}
${ }^{1}$ Department of Operative Dentistry and Dental Materials, Dental School, UFU - Federal University of Uberlândia, Uberlândia, MG, Brazil

${ }^{2}$ Department of Operative Dentistry and Dental Materials, Dental School, UNICAMP - University of Campinas, Campinas, SP, Brazil
\end{abstract}

\begin{abstract}
Dental ceramics present excellent ability to reproduce the natural teeth regarding esthetic and biomechanics. Recently, due to the advancement of ceramic technology, metal-free restorations were developed. However, the traditional metal-ceramic restorations still present the requirements of high strength, long survival in the oral environment and favorable aesthetics. In this context, it is essential to know the specificity of each ceramic system available in order to apply it properly to various clinical situations. This report describes an integrated rehabilitation using metal-ceramic restorations of a patient at 50 years of age, who presented edentulous spaces, and previous unsatisfactory composite and amalgam restorations, and indirect metallic restorations, leading to compromised quality of life in both functional and psychosocial aspects. The impact on quality of life was measured using a generic instrument, OHIP-14, validated for the World Health Organization, which covers both the biological and the psychosocial dimensions. This instrument was applied to the patient before and after treatment. The patient had an overall OHIP-14 score of 28 before the treatment and after treatment the score decreased to 0 , showing that dental and oral health conditions are factors that do impact on the quality of life. Rehabilitation has provided functional and aesthetic restorations, harmony of the stomatognathic system and improvement of life quality.
\end{abstract}

Key Words: rehabilitation, metal-ceramic restoration, quality of life.

\section{INTRODUCTION}

Quality of life was defined by WHO as "the individual's perception of their position in life in the context of culture and value systems in which they live and in relation to their goals, expectations, standards and concerns" (1). In adults, the quality of life depends on the emotional and subjective interpretation given by individual facts and life events that is modulated by emotional attitudes contingencies, environmental and personal resources (2).

Regarding to oral health research, there is little evidence about whether perceived or normative oral problems influence on the quality of life generally. Most studies have addressed oral health related-quality of life as a multidimensional phenomenon represented by the combination of functional limitation, pain perceptions and aesthetics mouthparts (3), and its relationship to disease and poor oral function. Evidence from these studies have also indicated that the number of teeth represents a major role as a determinant of subjective oral health (4).

Oral health-related quality of life is conceptually different from the overall quality of life (5) and, in general, the instruments of oral health related quality of life are focused on negative experiences and functional disability (6) caused by dental problems. Successful aging related to oral health is a result of the combination of good oral health, good self-perceived oral health, good functional health, and satisfaction with the access 
to oral health care and with dental services (7). If oral health was not maintained and need to be restored, the correct procedures recovering function and aesthetics, it will contribute to an improved quality of life and consequently for successful aging (8). This boosts the scalability and research assistance in the search for indicators that reflect, more faithfully, the results of the treatments available. In this sense, objective measures of the impact produced by the involvement of oral health and its management are seen to be increasingly important in the selection of therapeutic approaches and in the evaluation of clinical trials, emerging as important tools for assessment of therapeutic success. This position requires the use of instruments to measure quality of life in conjunction with the clinical goals and functional capacity. A generic instrument, the OHIP-14 index, a simplified OHIP (Oral Health Impact Profile) index, which covers both the biological and the psychosocial dimensions has been used currently.

Over the past decade, the technology used in dental ceramics has advanced rapidly, generating new restorative materials, developing a number of novel all-ceramic crown and bridge systems capable to restore single anterior, posterior or multiple teeth. The search for new methods has been driven by patients who have high expectations of esthetic dentistry, including expectations on the longevity of the restorative procedures and concerns about the intraoral biocompatibility of metals (9). So, it is improved the importance of the aesthetic dentistry concepts, aiming optimize the esthetic and functional results with different all-ceramic systems.

Although the physical properties and strength of all-ceramic crowns have been improved, no study has demonstrated that they can provide the same longevity as metal-ceramic restorations. Thus, the decision to use an all-ceramic restoration should be made by evaluating a number of patient-related factors. What are the patient's esthetic expectations? Are there complicating occlusal relationships, and what is the level of parafunctional activity? Is there an anterior or posterior restoration? Is it a single-tooth restoration or a fixed partial prosthesis? Clinicians should use them when the esthetics of the restoration is more important than the absolute longevity (9). However, it is always critical for patients to understand that the long-term survival rates for allceramic restorations are likely to be lower than those for metal-ceramic restorations (10).

Traditional metal-ceramic restorations still have the primary requirements of high strength, good aesthetics and long survival in the oral environment. As the goal of any oral rehabilitation process is to provide functional and aesthetic outcomes, harmony of the stomatognathic system and improve patient's quality of life, metal-ceramic restorations are still considered an excellent treatment alternative.

This paper reports a case involving an integrated rehabilitation using metal-ceramic restorations in a 50-year-old patient, leading to improvement of the quality of life in both functional and psychosocial aspects.

\section{CASE REPORT}

A 50-year-old female patient with poor masticatory efficiency, pain during functional articulation and considerable dissatisfaction with her smile, mainly because of the shade of teeth, was referred to the Prosthodontics Specialization Course of the Federal University of Uberlândia, Brazil, for evaluation and treatment. Medical, dental and social history was collected.

Medical evaluation revealed history of facial paralysis on the left side (Fig. 1A). Intraoral clinical examination showed staining of teeth by tetracycline, unsatisfactory direct restorations on maxillary anterior teeth and unsatisfactory fixed prosthesis on maxillary
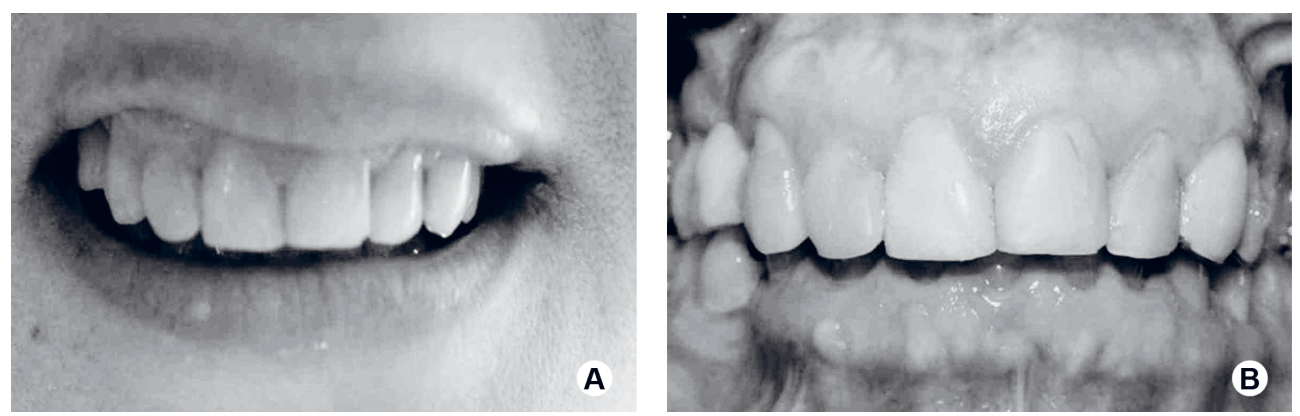

Figure 1. Intraoral view showing sequel of facial paralysis on the left side (A) and unsatisfactory maxillary anterior direct restorations (B). 
posterior teeth associated with posterior edentulous spaces (Figs. 1B and 2A). The patient reported that the maxillary anterior restorations had been placed less than 2 years before in private clinic, but she did not know the composite shades. The oral hygiene and clinical

Table 1. Assessment of oral health-related quality of life by OHIP-14 instrument.

\begin{tabular}{|c|c|c|}
\hline $\begin{array}{l}\text { Oral Health-Related Quality } \\
\text { of Life }\end{array}$ & $\begin{array}{c}\text { Before } \\
\text { Treatment }\end{array}$ & $\begin{array}{c}\text { After } \\
\text { Treatment }\end{array}$ \\
\hline \multicolumn{3}{|l|}{ Functional limitation } \\
\hline Trouble pronouncing words & 0 & 0 \\
\hline Sense of taste worse & 1 & 0 \\
\hline \multicolumn{3}{|l|}{ Pain and Discomfort } \\
\hline Painful aching in mouth & 0 & 0 \\
\hline Uncomfortable to eat foods & 2 & 0 \\
\hline \multicolumn{3}{|l|}{ Psychological Impacts } \\
\hline Been self-conscious & 4 & 0 \\
\hline Felt tense & 4 & 0 \\
\hline Difficult to relax & 3 & 0 \\
\hline Been embarrassed & 4 & 0 \\
\hline Felt life less satisfying & 3 & 0 \\
\hline \multicolumn{3}{|l|}{ Behavioral Impacts } \\
\hline Diet has been unsatisfactory & 1 & 0 \\
\hline Had to interrupt meals & 2 & 0 \\
\hline Been irritable with others & 2 & 0 \\
\hline Difficulty doing usual jobs & 2 & 0 \\
\hline Totally unable to function & 0 & 0 \\
\hline Score & 28 & 0 \\
\hline
\end{tabular}

conditions of the patient were satisfactory. Periapical and panoramic radiographs did not reveal any alterations.

Self-perceived oral health was obtained through the OHIP-14 index, which consists of 14 items organized into 7 subscales (functional limitation, physical pain, psychological discomfort, physical disability, psychological disability, social disability and physical impairment) that relate to aspects of oral health which can compromise the well being physical, psychological and social individual (11). The items have 5 response options: 'never $=0$ ', 'rarely $=1$ ', 'sometimes $=2$ ', 'often $=3$ ', 'always $=4$ '. The questions were asked in interviews before and after treatment to obtain the global ratings of the oral health and impact of the oral condition on her overall wellbeing from the evaluated patient (Table 1).

The treatment plan was established to provide functional and aesthetic rehabilitation of the stomatognathic system and improvement of the quality of life. In a rehabilitation procedure, all alternatives should always be explained to the patient, including the cost differences, the levels of tooth tissue removal, the expected clinical longevity, the time to conclude the treatment, and the predictability of the aesthetic result. Based on these factors, the patient was informed about the possible treatments options: direct or indirect anterior venners, anterior crowns, removable prostheses, fixed partial prostheses and implants.

The patient reported fear about the surgery for implant placement and, therefore, a complete rehabilitation with metal-ceramic was chosen. Initially, was discussed about performing all-ceramic crowns in the anterior region. However, since the canine was part of a fixed partial prosthesis of 5 elements, selected option decided in consensus between patient and professional time was: full rehabilitation with metal-ceramic.

The first step in any rehabilitation is shade

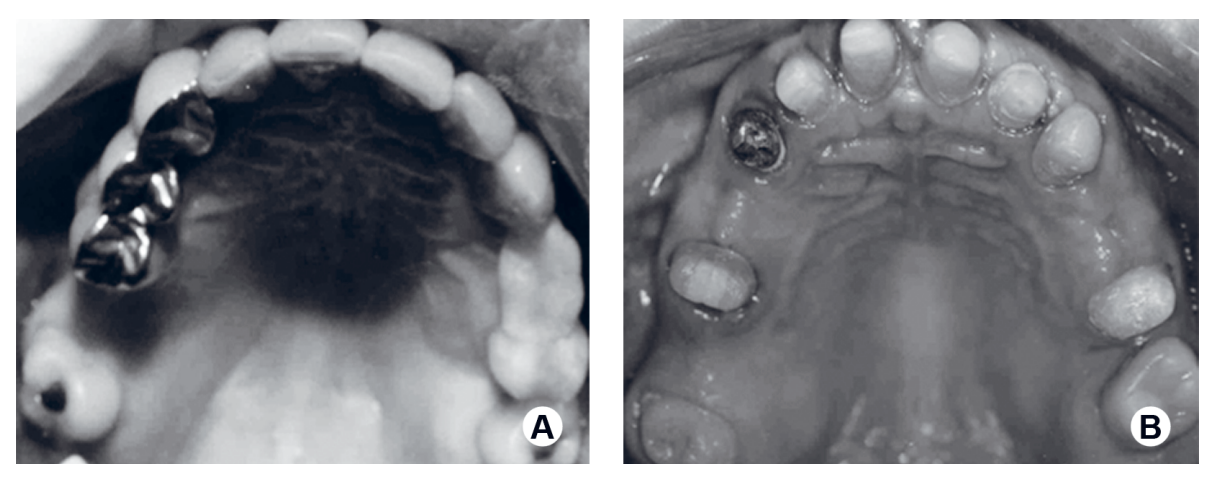

Figure 2. Intraoral view showing unsatisfactory maxillary posterior prosthesis combined with posterior edentulous spaces (A) and tooth preparation after rehabilitation planning (B). 
selection. First, the teeth should be carefully cleaned with slurry of pumice and chlorhexidine. Since the current shade was an aspect of dissatisfaction, in this particular case shade selection was not based only on the real shade, but also on the patient's desire. Maxillary and mandibular complete-arch impressions were made using irreversible hydrocolloid impression material (Hydrogum, Zhermack, Germany). Diagnostic casts were fabricated from Type IV dental stone (Velmix, Kerr Company, Detroit, MI, USA) and mounted on a semi-adjustable articulator (BioArt, São Carlos, SP, Brazil) using a face-bow transfer in a centric relation. The functional analysis showed presence of overbite, absence of most occlusal contacts, and decrease of vertical dimension of occlusions (DVO).

After verifying reduced DVO, a jig was made to obtain optimal height through the phonetic test. This was used as a guide for adjusting the DVO on both sides and all interims were made in this new and correct dimension. For this step, the teeth were prepared following the principles described to the rehabilitation with metalceramic pieces. During tooth preparation, it was observed the need for periodontal surgical intervention in order to increase the clinical crowns of anterior teeth, correct the gingival line and the bone defects in pontic areas (12). Thereafter, the patient was referred to the Periodontics Specialization Course of the Federal University of Uberlândia for evaluation.

It was confirmed the aesthetic necessity for the surgical procedure and the recommended interval between each surgery was 1 month. Always before the surgical procedure, intraoral antisepsis was performed with $0.12 \%$ chlorhexidine solution (Periogard; Colgate, São Paulo, SP, Brazil) rinse and extraoral antisepsis was performed with iodine solution (Riodine Tópico; Rioquímica Ind. Farmacêutica, São José do Rio Preto,
SP, Brazil). The first surgical procedure aimed to increase the clinical crowns of anterior teeth and correct the gingival line. Due the presence of keratinized gingiva covering the enamel, the excision tissue was required to achieve desired crown length, followed by reflection of the gingival flap and osseous resection to establish the 2 to $3 \mathrm{~mm}$ apical to the newly established gingival crest.

A partial-thickness mucoperiosteal flap was raised at the buccal and labial faces using a molt separator 2/4 (Dentoflex, São Paulo, SP, Brazil). After supracrestal flap elevation, the granulation tissue was removed with periodontal curettes (Hu-Friedy, Chicago, IL, USA). After removing the connective tissue, it was confirmed that the cementoenamel junction (CEJ) and the alveolar crest were in the same level. Ostectomy was then performed, the alveolar crest levels on the facials aspects of the teeth were re-contoured to be approximately 3.0 $\mathrm{mm}$ from the CEJ, which provides a physiologically adequate biologic width. Crown lengthening was carried out with round diamond burs (KG Sorensen, Barueri, SP, Brazil) in a high-speed handpiece with abundant water spray coolant. This procedure was refined with a periodontal chisel (Hu-Friedy) to reduce the height of all alveolar crest faces.

The buccal and labial flaps were stabilized, apically to the CEJ and 6-0 nylon sutures (Shalon Fios Cirúrgicos Ltda, São Luiz de Montes Belos, GO, Brazil) with 1.5-cm atraumatic needle. Saline-soaked gauze was applied with light pressure to the area for 5 min to avoid thick clot formation between the bone and flap. Following the surgical procedure, a periodontal dressing was applied (Coe-Pak; GC America Inc., Alsip, IL, USA).

After 1 month, other surgical procedure was performed in order to improve aesthetically in the pontic areas. First, the connective tissue graft was harvested
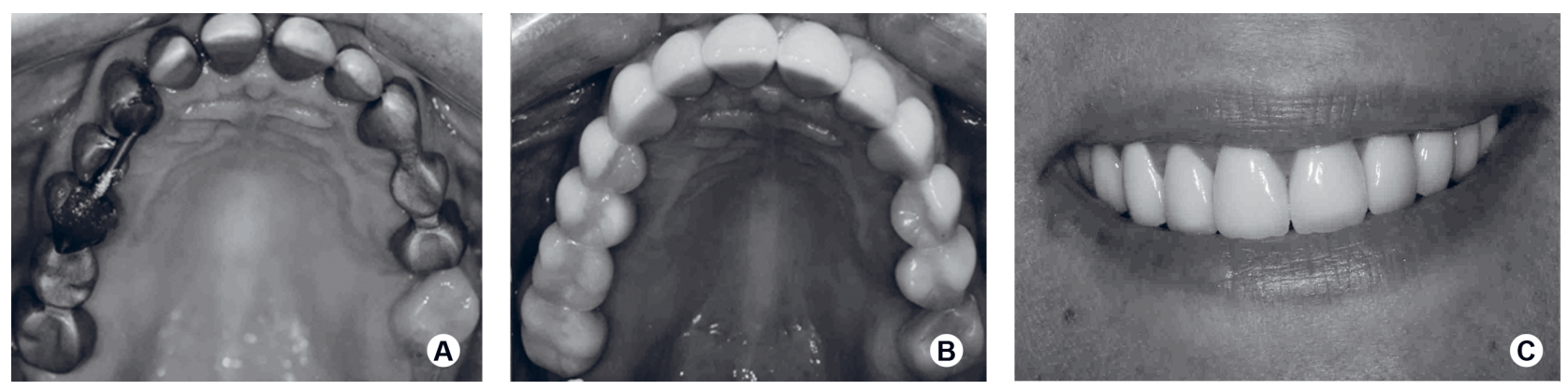

Figure 3. Clinical images showing try of metallic frameworks (A) and occlusal view of metal-ceramic restorations after cementation (B) and the patient's smile after completion of the treatment (C). 
from the palate between the distal aspect of canine and the mesial region of the first molar. Then, a connective tissue graft of an adequate size was harvested, and pressure was applied to the donor site with gauze soaked in saline after the graft had been taken. The donor area was then closed with monofilament suture. The connective tissue graft was positioned in the areas of bone depressions located near the apex of the premolars on both sides. Dry foil was applied to the recipient area and then a non-eugenol periodontal dressing (Coe-Pak, GC America Inc.) was placed over the dry foil to stabilize and protect the donor tissue for 8 days after the procedure.

As part of the postoperative care, it was recommended analgesic (sodium dipyrone, $500 \mathrm{mg}$, every $6 \mathrm{~h}$ for 2 days) and the patient was instructed to use, during this period, a $0.12 \%$ chlorhexidine solution rinse twice daily, to promote the reduction and inhibition of plaque formation. The periodontal dressing and the sutures were removed 7 days after surgery. Faced with data that confirm that regular professional maintenance enhanced the longevity of metal-ceramic fixed partial dentures (13), the patient was enrolled in a periodontal maintenance program (professional plaque control) weekly during the first month and then monthly after the surgeries.

One month after the last surgery, it was performed a refinement of tooth preparation to complete the restorative phase successfully and maintain periodontal health thereafter (Fig. 2B). The importance of waiting 1 month after the surgery is due to the fact that the periodontium has a tendency to reform a new physiological supracrestal gingival unit. Only after 1 month the gingival margin reaches about $60 \%$ of its final coronal position at interproximal sites and about $40 \%$ at buccal/lingual sites (14).

After completion of all preparations, a new complete-arch impression was made using a coping technique with a polysulfide, condensation-cured, elastomeric impression material (Permelastic; Kerr Company) combined with alginate (Hydrogum). The new casts were mounted on articulator (BioArt) for fabricating the metallic frameworks, and were tried to forward the soldering process (Fig. 3A). Then, the porcelain was applied on the metallic frameworks (Fig. 3B) (Super EX-3; Noritake Co. Inc., Cincinnati, OH, USA) and the set was checked for marginal integrity, proximal and occlusal relations and shape. The metal ceramic crowns were airborne-particle abraded with $50 \mu \mathrm{m}$ aluminum oxide abrasive (Microetcher Model
Er Precision Sandblaster; Danville Engineering Inc., Danville, CA, USA) and a zinc phosphate cement (SS White, Rio de Janeiro, RJ, Brazil) was used as a luting agent. The manufacturer's instructions were followed for all aspects of the seating procedure.

The patient was educated on an adequate toothbrushing technique and oral hygiene habits were required. The impact on the patient's quality of life had an overall OHIP-14 score of 28 before the treatment, decreasing to 0 after treatment, which shows that dental and oral health conditions are factors that do impact on the quality of life. The 1-year recall examination revealed no pathology associated with the rehabilitation and the patient's aesthetic and functional expectations were fulfilled (Fig. 4). The authors obtained patient consent to publish all images and documents relating to the rehabilitation treatment.

\section{DISCUSSION}

While metal ceramic systems have had a longer track record (13), various types of all-ceramic crown systems are also available (15). Some systems use a single-layer glass-ceramic material (e.g., Dicor, Dentsply/Caulk; IPS Empress, Ivoclar/Vivadent), whereas others have a dual-layer design (In-Ceram, Vident; Procera, Nobel Biocare) (15). These systems achieve a tooth-like appearance with the selection of an appropriately colored ceramic and the application of surface-coloring techniques (16).

However, it is so important to understand that simply placing an all-ceramic restoration instead of a metal-ceramic restoration will not guarantee outstanding esthetics. The clinician must accomplish a number of details meticulously to ensure success.

Traditionally, the evaluation of success has been based on clinical and radiographic methods. In this context, one of the most important details is proper tooth preparation, including finish-line geometry (17). Moreover, to attain optimum esthetics and adequate strength, the dentist must achieve adequate reduction to give the ceramist room to create a restoration with excellent esthetics, as well as to achieve physiological crown contours (9).

However, the recognition of the necessity for monitoring and evaluation of treatment under the patient's point of view has motivated the application of instruments for measuring quality of life in the definition of therapeutic success. The combination 
of health, longevity, job satisfaction, income, leisure, family relationships, mood, pleasure and even spirituality differentiate the human's life and results in a series of phenomena and situations that, abstractly, may be called quality of life (18). Using appropriate questionnaire techniques, it is possible to obtain valid and reliable information from people concerning their health-related quality of life.

In this paper, a generic instrument OHIP-14 measured the objective evaluation of quality of life related to health. Different methods of analysis are reported in studies using the OHIP-14 (19). Therefore, two methodologies were used for analysis, applied before and after treatment. The first referred to the content expressed as the sum of the points of the seven sub-scales on a scale of $0-4$, where higher scores represent worse self-perceived oral health (28 and 0 respectively). The results demonstrated the positive impact of restorative treatment with metal-ceramic in the patient's quality of life. However, confirmation of these effects requires further clinical investigation involving relevant number of the patients.

The aesthetic and functional recovery achieved with metal ceramic crowns combined with the periodontal surgery was an excellent therapeutic option for reestablishment of oral health and the quality of life. This case is a result of a cooperative and multidimensional approach to the patient.

\section{RESUMO}

As cerâmicas dentais são conhecidas pela excelência em reproduzir artificialmente dentes naturais. Recentemente, devido ao aprimoramento da tecnologia cerâmica, surgiram as restaurações livres de metal. Entretanto, as tradicionais metalocerâmicas ainda preenchem adequadamente os requisitos de alta resistência, longa sobrevida em meio bucal e estética favorável. Neste contexto, é fundamental conhecer a especificidade de cada sistema cerâmico a fim de indicá-lo adequadamente às diversas situações clínicas. Este artigo relata um caso de reabilitação integral e integrada de paciente de 50 anos de idade, portador de espaços edêntulos, restaurações protéticas posteriores e restaurações diretas anteriores insatisfatórias, resultando em comprometimento da qualidade de vida nos âmbitos funcional e psicossocial, utilizando coroas metalocerâmicas. O impacto na qualidade de vida foi mensurado utilizando um instrumento genérico, OHIP-14, validado pela Organização Mundial de Saúde, que abrange tanto a dimensão biológica, como a dimensão psicossocial. Este instrumento foi aplicado à paciente antes e após o tratamento, obtendo pontuação total de 28 e 0 respectivamente, o que mostra que a condição de saúde oral representa fator de grande impacto sobre a qualidade de vida. A reabilitação oral proporcionou restabelecimento funcional e estético, harmonia do sistema estomatognático e melhoria da qualidade de vida da paciente.

\section{REFERENCES}

1. The World Health Organization Quality of Life assessment (WHOQOL): position paper from the World Health Organization. Soc Sci Med 1995;41:1403-1409.

2. Xavier FM, Ferraz MP, Marc N, Escosteguy NU, Moriguchi EH. Elderly people's definition of quality of life. Rev Bras Psiquiatr 2003;25:31-39.

3. Gift HC, Atchison KA, Dayton CM. Conceptualizing oral health and oral health - related quality of life. Soc Sci Med 1997;44:601608.

4. Steele JG, Sanders AE, Slade GD, Allen PF, Lahti S, Nuttall $\mathrm{N}$, et al.. How do age and tooth loss affect oral health impacts and quality of life? A study comparing two national samples. Community Dent Oral Epidemiol 2004;32:107-114.

5. Seildl EM, Zannon CM. Quality of life and health: conceptual and methodological issues. Cad Saude Publica 2004;20:580-588.

6. Brondani MA, MacEntee MI. The concept of validity in sociodental indicators and oral health-related quality-of-life measures. Community Dent Oral Epidemiol 2007;35:472-478.

7. Atchison KA, Andersen RM. Demonstrating successful aging using the International Collaborative Study for Oral Health Outcomes. J Public Health Dent 2000;60:282-288.

8. Barnfather KD, Brunton PA. Restoration of the upper dental arch using Lava all-ceramic crown and bridgework. Br Dent J 2007;202:731-735.

9. Donovan TE. Factors essential for successful all-ceramic restorations. J Am Dent Assoc 2008;139:14S-18S.

10. Denry I, Kelly JR. State of the art of zirconia for dental applications. Dent Mater 2008;24:299-307.

11. Bandéca MC, Nadalin MR, Calixto LR, Saad JR, da Silva SR. Correlation between oral health perception and clinical factors in a Brazilian community. Community Dent Health 2011;28:64-68.

12. Dias LZ, Novaes AB Jr, Novaes AB. Prosthesis-periodontics relationship. 2. Increase of clinical crown and surgery for prosthetic purposes. Braz Dent J 1991;2:19-26.

13. Walton TR. An up to 15 -year longitudinal study of 515 metalceramic FPDs: Part 2. Modes of failure and influence of various clinical characteristics. Int J Prosthodont 2003;16:177-182.

14. Pontoriero R, Carnevale G. Surgical crown lengthening: a 12-month clinical wound healing study. J Periodontol 2001;72:841-848.

15. Polack MA. Restoration of maxillary incisors with a zirconia allceramic system: a case report. Quintessence Int 2006;37:375-380.

16. Shirakura A, Lee H, Geminiani A, Ercoli C, Feng C. The influence of veneering porcelain thickness of all-ceramic and metal ceramic crowns on failure resistance after cyclic loading. J Prosthet Dent 2009;101:119-127.

17. Donovan TE, Chee WW. Cervical margin design in contemporary esthetic restorations. Dent Clin North Am 2004;48:417-431.

18. Goursand D, Paiva SM, Zarzar PM, Pordeus IA, Grochowski R, Allison PJ. Measuring parental-caregiver perceptions of child oral health-related quality of life: psychometric properties of the Brazilian version of the P-CPQ. Braz Dent J 2009;20:169-174.

19. Fernandes MJ, Ruta DA, Ogden GR, Pitts NB, Ogston SA. Assessing oral health-related quality of life in general dental practice in Scotland: validation of the OHIP-14. Community Dent Oral Epidemiol 2006;34:53-62. 